\title{
Learning Wisdom beyond Ma'tammu Tedong of Toraja People: Using Semiotic Approach to Understand Myths and Ideology
}

\author{
Rita Tanduk \\ Indonesian Christian University, Toraja, Indonesia. \\ tandukrita@gmail.com
}

\author{
ARTICLE HISTORY \\ Received : 2019-06-28 \\ Revised : 2019-07-08 \\ Accepted : 2019-11-08
}

\section{KEYWORDS}

Ritual Speech

Rambu Solo

Myth

Ideology

\begin{abstract}
This paper discusses the meaning beyond ma'tammu tedong of Toraja People using semiotic approach to reveal wisdom beyond it. Participant observation methods used with field notes, recording, and interview techniques completed the data collection. The ritual text of the Ma'tammu Tedong or buffalo meeting ceremony in rambu solo' ceremony is a symbolic form, parallelism, and metaphor which also constructs the meaning of customary ritual myth. Through the ritual remarks on the seven types of buffalo in the ceremony of rambu solo' indicating views, concepts, and motivations are used as guidelines for life for Toraja people. The result of the research shows that, (1) the customary ritual text of buffalo meeting is symbolic, parallelism, and metaphor characteristics that represent myth meaning, (2) customary ritual text of buffalo meeting is to construct myth and ideology about Toraja character value. The value of the characters is represented by the seven types of buffalo in the customary ritual ma'tammu tedong namely, (a) balian buffalo represented as a leader figure or role model; (b) bonga buffalo as torch in human life of Toraja; (c) pudu' buffalo as guardians in maintaining the life of the Toraja; (d) todi' buffalo as a unifier that strengthens kinship ties; (e) sokko' buffalo describes a polite and humble person; (f) tekken langi' buffalo as a safeguard that reconciles the Toraja over the conflict; (g) sambao' buffalo as customary guardians for customary offenses. Those values indicate the existence of the relation between man and Almighty and man with others. Also, they strengthen the character of human life of the Toraja and nation character.
\end{abstract}

\section{Introduction}

The ritual rhymes are delivered in the form of Toraja oral literature or with other expressions that Toraja people often call kada-kada tominaa or kada tantanan. Rituals are remarked by a Tominaa. In Toraja language dictionary (2016) Tominaa is a man who is good at praying and being an advocate in offerings. The rituals are typically different from the daily language. Ritual rhymes are used to express individual prayers and expectations (Duranti, 2004: 436).

Furthermore, procession of ma'pasa tedong ceremony (buffalo meeting) in the ceremony of rambu solo' (funeral ceremony) is followed by ritual utterances as complementary. This is committed as a sign of respect and sanctification of buffaloes that will be slaughtered in rambu solo' ceremony. Enough knowledge and understanding are needed to learn and interpret the meaning of rituals appropriately. The ritual text as homage to the buffalo in rambu solo' ceremony illustrates various meanings that affect the life pattern and character of Toraja people. The meaning of the myths which arae cast through the traditional ceremony is a mental concept used by Toraja people to divide reality and categorize it, so that others can understand the reality. Thus, the procession of rambu solo' ceremony is not merely a spectacle and complement of traditional ceremonies but also used as a source of inspiration and innovation in the preservation of the noble values of the nation's culture.

\section{Literature Review}

\subsection{The Concept of Myth}

Myth of the Greek word means," the word, the story of the Gods, and can be defined as a story or collection of elements of the story considered to be a disclosure, and therefore implicitly symbolizes certain aspects within human existence and trans-human". Myth is the basic phenomenon of human culture. According to Lévi Strauss (in Nöth, 1990), myth becomes a special object of semiotic text. Beginning with Barthes, myth has been 
interpreted as a semiotic phenomenon of everyday culture. In addition, he defines myth as a metaphysical narrative, a text that must be interpreted on two levels. First is birth level, which refers to the action of the agent or the perpetrator of the myth (called the practical level of myth). The second is inner level, which refers to the questions of human existence and the cosmos (elements of nature).

\subsection{Myth as a Semiology System}

Semiotics (semiology) of Roland Barthes refers to de Saussure investigating the relationship between signifier and signified on a sign. The relationship of signifier and signified is not the equality, but the equivalent, that is, the two are correlated. Barthes develops two staggered systems that allow for creating some levels of meaning, which are also the level of denotation and connotation. Denotation is the level of signification that describes the relationship between the signifier and the signified or between its sign and reference to reality, which is explicit, direct and definite.

\section{First level}

The denotative meaning in this case is the meaning in what appears. Denotation is a sign whose signature has a high convention or agreement level. Besides, connotation is a level of signification that explains the relationship between signifier and signified, in which operate meaning that is not explicit, indirect and uncertain (means open to possibilities). It creates the meaning of the second layer, which is formed when the signifier is associated with various psychological aspects such as feelings, emotions or beliefs.

The connotation develops more broadly than it does in linguistics. Barthes, (1957) presents the concept of connotation as a "second meaning" based on a cultural, political, or ideological view of meaning. The meaning we see is deeper, conventional, that is, the meanings associated with myth. The myth of Barthes's understanding of semiotics is the coding of social meanings and values (which are either arbitrary or connotative) as natural. The level of sign and meaning of Barthes can be described as follows.

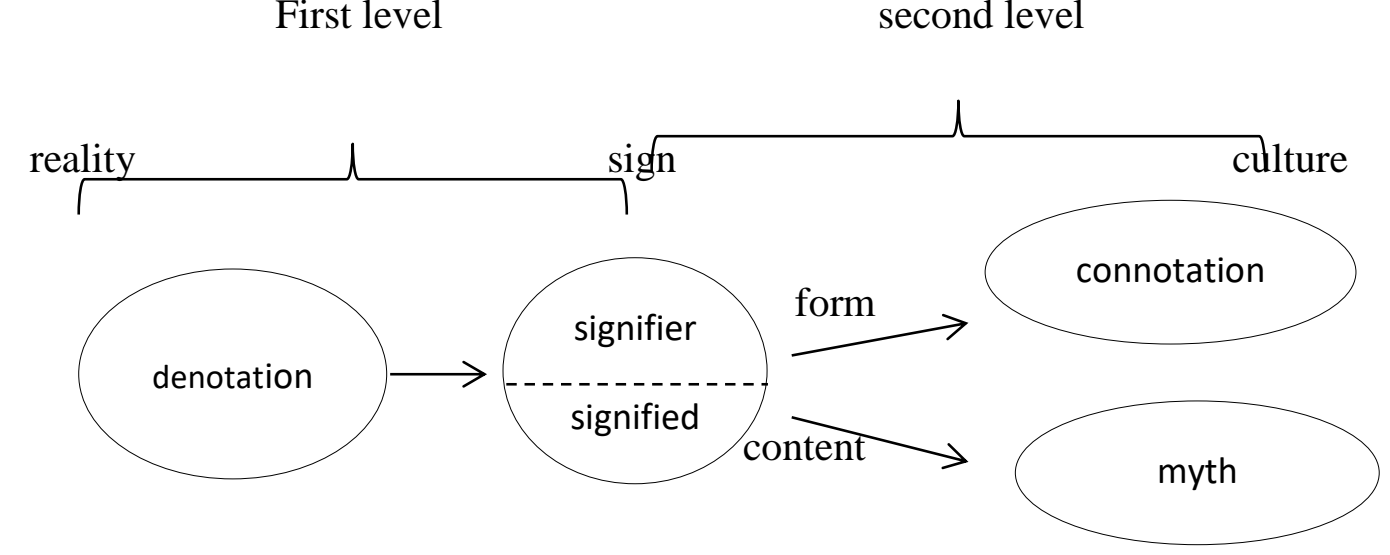

Figure 1. Two staggered systems of Barthes. In the second level, sign system from first level is inserted in the cultureal system (Fiske, 1990)

According to Barthes (1957: 152), myth is a communication system, that is a message; myth is the meaning of a form. Besides, myth is not determined by the object of its message, but by the way the myths express the message itself. In myth there are three patterns of dimensions just mentioned earlier: signifier, signified and signs. Myth is a special system built from a series of semiological chains that have existed before. myth is a second level semiological system. The sign (ie, the total mix between concept and image) in the first system, becomes a signifier on the second system.

Similarly, myth is the meaning of a form as well as myth is formed by associating it with social-cultural aspects in society outside itself and at the same time as system of referent system. Furthermore, myths create a new object backed by a certain (ideological) view. Through mythological analysis in the semiology of Roland Barthes, the sign system is as a totality in forming meaning.

\subsection{Ideology}

Study of ideology leads to semiotic interdisciplinary relationships with philosophy and various social sciences. As a science, ideology relates to modern semiotics because of its early history. At present, semiotic analysis of ideology is a topic repeatedly discussed in semiotic theoretical and semiotic of texts, especially in semiotic studies critically on various types of texts. Further, a new concept of ideology by Stuart Hall (in Van Dijk, 1998: 9), 
by Ideologi I mean the mental frameworks- the languages, the concepts, categories imagery of thought, anda the system of representation - wich different classes and social groups deploy in order to make sense of, figure out and render intelligible the way society works.

The definition explains that ideology is not limited to making sense to society, but also to functioning to regulate social practices. This refers to the role of ideology in the stabilization of certain forms of power and domination. Concerned with new concepts and ideas, ideology serves as an encounter between social structure and social cognition. In this sense, ideology can be briefly defined as the basis of social representation shared by members of the group. This means that ideology allows people, as members of a group, to organize many social beliefs about what is going on, good or bad, right or wrong, for them to act accordingly.

\subsection{Customary Ritual of Rambu Solo'}

In the practice of Toraja life, custom and aluk become one unity which is applied from generation to generation which eventually becomes habit ( $a d a^{\prime} /$ custom). This is reflected in existing custom ceremonies such as aluk rambu solo' or ceremony of death. The death-related ceremonies are classified in aluk rambu solo' or aluk rampe matampu'. This phrase consists of two words: rambu', which means smoke; and solo' means down or go down. So, rambu solo' literally means smoke went down, while aluk rampe matampu' means west. It is called rambu solo' because the offering rituals begin to take place as the sun begins to set, and is called rampe matampu' because it is carried out in the west of tongkonan house and when the sun is in the west. According to the Toraja community philosophy, smoke is a symbol of the ceremony (a gathering activity followed by a joint meal activity), and descending is a symbol of grief (Manta, 2004).

Death is discerned as a 'ceremony' not because of its festive mood, but mainly because of its free acceptance of the fate of death itself. Death is a transition of life from this world to a new world called puya, a world of the dead. This is the spirit of the dead man who lives his life. But to get to puya, the dead needs enough facilities and supplies for travel. The means or capital of the dead journey to the world of puya is symbolized in sacrifice of sacrificial animals; pig and buffalo. This sacrifice becomes the 'vehicle' to gate of puya. The large number of animals sacrificed usually indicates the social position or social status in the community. Those who have the highest status in society are obliged to be fully solemnized (dipasundun aluk atau dirapa'i), even the type of animal sacrificed must be complete, otherwise it is usually a barrier for them to enter the world of the dead (puya).
The rituals through customs that have been inherited by Torajan society from generation to generation in the form of rambu solo' require the living family to hold a feast or ceremony as the last sign of honor to the deceased (aluk rampe matampu or mamarran mata). The expression of mamaran mata by the Toraja ethnicity is stated: " To na indanriki' lino, To na pake sangattu' Kunbai lau'ri Puyo, Pa'tondokkan marendeng ", meaning we are only a world loan and used temporarily, because, in puya (hereafter) is our eternal land (Palembangan, 2007).

\section{Method}

This type of qualitative-interpretative research is a method used in producing descriptive research data. The research data were obtained from verbal texts that were ritual utterances by a Tominaa as protocol in ceremony of rambu solo', and nonverbal text that was in the form of description of context as supporting verbal text. Data collection was obtained by direct participant observation method which aimed to observe social activities, buffalo, and physical aspect of social situation. Data were analyzed and interpreted through direct interviews with cultural sources to obtain data validity.

\section{Findings and Discussion}

The sacrifice of a buffalo in a customary ceremony ma 'tammu tedong creates myth. Through the honor of the buffalo in the ceremonies, this does not only convey the identity or the advantages possessed but also makes the buffalo mean something human (social and cultural meaning) for Toraja people. In this context, Toraja people naturalize by conveying two objects (signs) on rambu solo' ceremony, ie the first object (sign) conveys identity as a material function (denotation) and the second object (signifier) is the element of social-cultural value that its meaning is transferred to the first object, for example the wishes, hopes, ideals that serve as guidelines for the life of Toraja people.

The analysis of the data presented shows the significance of denotation, connotation, and myth through the symbolization of the seven types of buffaloes at the traditional ceremony ma'tammu tedong'.

[1]. Ritual text to balian buffalo on text segment,

1) Iko balian,

'You, balian'

2) tedong ma'buluk aluk';

karambau ma'songgo bisara

'buffalo with customary fur' 
The text states that balian buffalo is referred as a traditional buffalo in rambu solo' ceremony ritual. In terms of meaning, myth-connotation explains that balian buffalo is seen as the 'main or forefront' buffalo which means to describe the figure of an exemplary leader. This is supported by the following verbal texts,

3) Iko Ianna poparandangan dandanan sangka; ' 'you become a pillar of customary ceremony'

\section{4) Iko Ianna dipa 'pallidanian penanda bisara} 'you become a foundation in customary ceremony'

Based on the context, balian buffalo occupies the first row among other buffalo types in rambu solo' ceremony. The balian buffalo is represented as a leader or role model who will show the way for salvation for the life of Toraja people.

[2]. Bonga buffalo on some segments of the ritual text mentioning the name and character, this can be shown in the text segment form (5) Iko bonga' batu saleko (You, stripe buffalo) which means bonga buffalo is a type of buffalo which has striped skin (black- white). In terms of meaning, myth-connotations explain that the color of stripes (black and white spots) on bonga buffalo is described as light. Like humans, the word 'light' is associated with a figure that gives torches or guidance to family and community clusters. It is shown through the verbal text (6) Iko bonga' batu saleko (You, bonga, the symbol of customary stakeholders in the village). The meaning shows bonga buffalo is represented as counselor or guide.

[3]. Pudu' buffalo through the ritual text described as form of identity with the mention of name and its characteristics and superiority. As can be seen on the verbal texts (7-8) Iko Pudu', Lolosu kandaurena Pongki Kumorrok (You, black hair, the descendant of aristocracy of Pongki Kumorrok) described that pudu' buffalo is a buffalo with thick black furry which is strong and stocky that is derived from the noble descendant of Pantilang Luwu named Pongki Kumorrok. Based on the meaning of myth-connotation, the existence of pudu' buffalo symbolized as the basis of strength or pedestal in customary ceremonies for nobility. Therefore, the term protector which is represented by $p u d u$ ' buffalo from its power can undoubtedly maintain and guard the life of Toraja people. The function of ritual text meaning of pudu' buffalo becomes the basic understanding of Toraja people to cultural value through the symbol attached to self of pudu' buffalo. Pudu' buffalo represents the value that describes Toraja's human self-character.

[4]. Todi' buffalo through the ritual text has several forms of text segments that state the mention of identity of name and attributes attached to it. Like verbal text:
9) Iko todi,

'You, a white sign on head'

10) Toding kalua'na rara makamban,

'A sign of kinship greatness'

\section{1) Tanda tasikna buku tangsipeaderan}

'A sign of family cluster of tongkonan'

The meaning of the text states todi' buffalo has a white mark on the head that signifies the meaning of kinship of tongkonan family. In terms of meaning, mythconnotation, todi' buffalo symbolized as tongkonan, means the place of family group cluster that is started from one grandmother. Tongkonan meaning is associated with peace between relatives in one family, so todi' buffalo is represented as the unifier of family clusters. So, the inherent symbols of todi' buffalo form the value of Toraja character as a figure that can unite the family of tongkonan family clusters.

[5]. Fifth, the text segment form of sokko' buffalo denotes the mention of identity as its name and character. This appears on the verbal text (12-14) Iko Sokko', tanduk tuo rokko/tama, ma 'tannun-tannun papatui inaa (You, the thorns grow down, horns grow down symbolizes humility). This means sokko' buffalo with its horn form symbolizing humility. The meaning of mythconnotation, the humble figure is associated with a polite attitude. This is related to verbal texts (15) Tangla situlak ia kada lan tammuan mali' (hopefully, in the family meeting there is no dispute), meaning the presence of sokko' buffalo is described as a polite figure in making decisions so that deliberations in the family can run well. Thus, the meaning of sokko' buffalo symbols in traditional ceremonies of rambu solo' represents the cultural values that shape the life character of Toraja people.

[6]. Tekken langi' buffalo with verbal texts (16-18) describes his identity as Iko tekken langi', unnindo' basse kasalle, unnambe' panda dipamaro'son (You, animal with the feet of iron, the sign of the great covenant with oath, the symbol of peace). The verbal text states that tekken langi' buffalo has the power to hold an oath or customary agreement over the dispute that occurs within the community. If viewed from the meaning of mythconnotation, tekken langi' buffalo symbolizes the figure for peace that will secure the dispute or customary violations that occurr in the community. The inherent symbol of tekken langi' buffalo represents Toraja's human self-character about value of peace.

[7]. The ritual text of sambao' buffalo declares selfnaming through the characteristics and advantages possessed in customary ceremonies. As in the verbal text (19-21) which states Iko sambao', Tedong ma'kuli' 
pindan, Umpokuli' bulo bangko (You, gray animal, white or clean, thick and smooth skin buffalo) means sambao' buffalo skin is clean, thick, and also smooth. The meaning of myth-connotation, skin color of sambao' buffalo is a reflection of a clean light. The customary cleansing symbol attached to sambao' buffalo gives the indication of traditional restoration of customary abuses committed, it is seen in the text (22-23) kemakambanmi dandanan sangka' dilenda pesalu, kemanimpa 'i penanda bisara dilenda sumallan (many who violate customary rules, many who keep the customary rules will get rewards). The meaning of symbols given to sambao' buffalo serves as the basis of customary rules for customary violations or conflicts, therefore sambao' buffalo is referred to as customary restorer. On the basis of the inherent symbolism of sambao' buffalo represents a cultural value that describes the value of Toraja people character.

The sacrifice of a buffalo in a rambu solo' ceremony 'creates a myth. Through the honor of the buffalo in the ceremonies, it does not only convey the identity or the advantages possessed but also makes the buffalo mean something human (social and cultural meaning) for Toraja people.

\section{Conclusion}

The text of buffalo ritual is a form of homage to the buffalo in rambu solo' ceremony. It is as a sacred expression spoken by tominaa that contains hope, prayer, admonition, and customary rules for life of Toraja people. It can be noted that the symbolization of seven types of buffalo characterizes Toraja people by understanding the life values. The symbolization of the seven species of buffalo in rambu solo' ceremony expresses the values of exemplary and life view for Toraja people. Those values are, (a) balian buffalo is represented as a leader figure or role model; (b) bonga buffalo as torch or light in life of Toraja people; (c) pudu' buffalo is as guardian in maintaining the life of Toraja people; (d) todi' buffalo is as a unifier that strengthens kinship ties; (e) sokko' buffalo describes a polite and humble person; (f) tekken langi' 'buffalo is as a safeguard that reconciles Toraja people over the conflict; (g) sambao' buffalo is as customary guardians for customary offenses.

Denotation meaning of the ritual text explains the forms of reverence of the buffalo in rambu solo' solemn rituals which mention names and characteristics of the buffaloes. Furthermore, connotation meaning relates to the meaning of buffaloes based on various views of Toraja people that are conventional. It can be identified that connotation meaning is what shapes the concepts and views of Toraja people to create myths.
Toraja people through their customary rituals naturalize their concepts and views from the buffalo ritual text into an acceptable and reasonable idea or opinion in society. The ritual text as one form of Toraja oral literature that still shows its existence in the defense of the cultural character of the nation through its customary ceremony.

\section{References}

Barthes, Roland. (1972). Membedah Mitos-Mitos Budaya Massa. Jakarta: Jalasutra.

Barthes, Roland. (1973). Elements of Semiology. New York. Hill and Wang

Barthes, Roland. (1957). Mythologies. Paris: Edition de Suil

Bell, C. (1992). Ritual Theory Ritual Practice. New York Oxford: Oxford University Press

Daniels, H. (2015). Mediation: An expansion of the socio-cultural gaze. History of the Human Sciences, 28(2), 34-50.

De Saussure, F. (2011). Course in general linguistics. Columbia University Press.

Duranti, A. (1997). Linguistics Anthropology. New York: Cambridge UniversityPress.

Duranti, A. (2004). A Companion to Linguistics Anthropology. USA: Blackwell Publishing Ltd.

Feng, D. (2016). Promoting moral values through entertainment: a social semiotic analysis of the Spring Festival Gala on China Central Television. Critical Arts, 30(1), 87-101.

Fiske, John. (1990). Cultural and Communication Studies. London: Routledge.

J. Tammu, dan H.Van deer Veen (2016). Kamus TorajaIndonesia. Rantepao: Sulo

Noth, Winfried. (1990). Handbook of Semiotics. USA :The Association of American University Press.

Palembangan, Frans. B. (2007). Aluk, Adat, dan Adat Istiadat Toraja. Rantepao: Sulo

Van Dijk, Teun A. (1998). Ideology a Multidisciplinary Approach. London: Thousand Dark.

Van Dijk, Teun A. (1998). Language Ideologies (Practice anda Theory). New York: Oxfort University Press.

Zittoun, T., \& Gillespie, A. (2015). Internalization: How culture becomes mind. Culture \& Psychology, 21(4), 477-491. 